\title{
Clinical and laboratory characteristics of children with Kawasaki disease
}

\author{
Kawasaki hastalığı bulunan çocukların klinik ve laboratuvar özellikleri
}

\author{
Fatih Akın", Melike Emiroğlu ${ }^{2}$, Ahmet Sert ${ }^{3}$, Şükrü Arslan ${ }^{4}$, Ece Selma Solak $^{1}$
}

\begin{abstract}
Objective: In this study, we aimed to evaluate clinical and laboratory characteristics of patients with Kawasaki disease (KD) in Konya region of Turkey.

Methods: The hospital records of patients who were hospitalized with the diagnosis of KD in the Pediatrics Clinics of Konya Training and Research Hospital between May 2010 and June 2012 were reviewed retrospectively.
\end{abstract}

Results: Seven cases were found to have the diagnosis of KD, two of whom were incomplete KD. Oropharynx changes were the most common $(100 \%)$ feature in our patients. Five (71\%) patients had bulbar conjunctivitis. Three $(43 \%)$ patients had erythema at the site of BCG inoculation. Adenopathy was present in all of our patients with the classical form. A desquamation was observed in one case at the seventh day of fever. No cardiac manifestation was seen. Elevated erythrocyte sedimentation rate and thrombocytosis were present in all patients. All of the patients were received intravenous immunoglobulin in the first ten days of the fever.

Conclusion: KD should be considered as a possible diagnosis in any child presenting with prolonged fever. BCG reaction can be attributed as a diagnostic criterion for incomplete form of the disease especially in countries where BCG vaccination is routinely performed. Early treatment is essential to prevent cardiovascular complications.

Key words: Kawasaki disease, vasculitis, BCG reaction, children

\section{INTRODUCTION}

Kawasaki disease (KD) is a self-limited vasculitis of unknown origin, characterized by fever, rash, conjunctivitis, changes in the oral mucosa and ex-

\section{ÖZET}

Amaç: Bu çalışmada, kliniğimizde Kawasaki hastalığı $(\mathrm{KH})$ tanısıyla takip ettiğimiz vakalarımızın klinik ve laboratuvar özelliklerini sunmayı amaçladık.

Yöntemler: Konya Eğitim ve Araştırma Hastanesi Çocuk Sağlığı ve Hastalıkları Kliniği'ne Mayıs 2010 ve Haziran 2012 tarihleri arasında KH tanısıyla yatıılarak takip edilen hastaların kayıtları retrospektif olarak incelendi.

Bulgular: Yedi vakanın Kawasaki hastalığı tanısıyla izlendiği tespit edildi. Bu vakaların ikisi inkomplet Kawasaki hastalığı tanısı almıştı. Hastalarımızın tümünde (\%100) orafarenks bulguları mevcuttu. Beş hastada (\%71) bulbar konjonktivit vardı. Üç hastada (\%43) BCG aşı yerinde eritem gözlendi. Klasik Kawasaki hastalığı tanısı alanların tümünde servikal adenopati mevcuttu. Bir hastada ateşin yedinci gününde ortaya çıkan ve bir hafta içinde düzelen periungual deskuamasyon gözlendi. Tüm hastalarımızda yüksek eritrosit sedimentasyon hızı ve trombositoz mevcuttu. Takipleri süresince hastaların hiçbirinde kardiak komplikasyon gözlenmedi. Hastalarımızın tümü ateşin ilk 10 günü içinde IVIG tedavisi almıştı.

Sonuç: Uzamış ateş şikayetiyle gelen her hastada ayırıCı tanıda $\mathrm{KH}$ düşünülmelidir. BCG aşısının rutin olarak uygulandığı ülkelerde BCG aşı yerinde gelişen eritem özellikle inkomplet KH'nda tanı kriteri olarak kullanılabilir. Kardiyovaskuler komplikasyonların gelişmesini önlemek açısından hastalığın erken tanısı tedavisinin başlanması çok önemlidir.

Anahtar kelimeler: Kawasaki hastalığı, vaskülit, BCG reaksiyonu, çocuk

tremities, cervical lymphadenopathy, and dilatation or aneurysms of the coronary and other arteries [1]. It was firstly described by Tomisaku Kawasaki in 1967 as acute febrile mucocutaneous syndrome [2] It is one of the most common vasculitis of child-

${ }^{I}$ Department of Pediatrics, Konya Training and Research Hospital, Konya, Turkey

${ }^{2}$ Department of Pediatric Infectious Diseases, Selçuk University, Selçuklu Medical Faculty, Konya, Turkey

${ }^{3}$ Department of Pediatric Cardiology, Konya Training and Research Hospital, Konya, Turkey

${ }^{4}$ Department of Pediatric Nephrology, Konya Training and Research Hospital, Konya, Turkey

Yazışma Adresi /Correspondence: Fatih Akın,

Konya Training and Research Hospital, Department of Pediatrics, Meram, Konya, Turkey Email: drfatihakin@gmail.com

Geliş Tarihi / Received: 14.08.2014, Kabul Tarihi / Accepted: 12.03.2015

Copyright @ Dicle Tıp Dergisi 2015, Her hakkı saklıdır / All rights reserved 
hood. Ozen at al. reported that it was the second common vasculitis (9\%) in Turkey after HenochSchönlein purpura, among patients admitted to rheumatology outpatient clinics [3]. It is the most common acquired heart disease in Japan and USA [4]. Although the exact etiology remains unknown, clinical features suggest that it is a disease triggered by an infectious disease in genetically prone patients [5]. Erythema at the site of Bacille CalmetteGuerin (BCG) inoculation is rare, but it is a specific sign of KD [6]. Here we report our experience about 7 children with KD.

\section{METHODS}

The files of patients who were hospitalized in Konya Training and Research Hospital Pediatrics Clinic between May 2010 and June 2012 were reviewed retrospectively. 7 cases were found to have the diagnosis of KD. Informed consent was obtained from the parents of the cases. Case presentations were the followings:

\section{CASE 1}

A 15-month-old girl had been referred with a differential diagnosis of KD. She had a history of high grade fever for 7 days and a maculopapular rash for 5 days. She had been hospitalized for 4 days in the previous hospital and given antibiotics including ceftriaxone, vancomycin and ampicillin-sulbactam. On the third day of hospitalization, swelling of the hands and feet, and unilateral cervical lymphadenopathy had occurred. On physical examination, irritability was remarkable. Her body temperature was $38.8^{\circ} \mathrm{C}$. She had a blood pressure of $110 / 70$ $\mathrm{mmHg}$ and pulse rate was $120 / \mathrm{min}$. She had dry and cracked red lips and her tongue was hyperemic with hypertrophied papillae. There was anterior cervical lymphadenopathy measuring $2 \times 1.5 \mathrm{~cm}$ and a maculopapular rash over the lateral regions of both femurs. Both hands and feet were swollen (Picture 1). Nonpurulant bulbar conjunctivitis was not apparent but bulbar vascularity was increased. A diagnosis of KD was made and the patient received intravenous immunoglobulin (IVIG) and aspirin. She became afebrile 48 hours after IVIG infusion.

\section{CASE 2}

A 4-year-old boy had presented with complaints of fever, vomiting, hyperemia of eyes and diffuse rash. While fever and hyperemia on eyes had been started 3 days ago, rash was noticed on the admission day. Physical examination revealed a temperature of $38.0^{\circ} \mathrm{C}$, blood pressure of $75 / 45 \mathrm{mmHg}$ and pulse rate of $120 / \mathrm{min}$. Bilateral nonpurulant bulbar conjunctivitis was apparent. He also had a diffuse maculopapular rash, dry and cracked red lips with a strawberry tongue. Swelling of both hands and feet, an anterior cervical lymphadenopathy measuring $2 \times 1 \mathrm{~cm}$ were observed. There was no desquamation. On the second day of admission he still had a persistent fever reaching up to $39.4^{\circ} \mathrm{C}$. A diagnosis of $\mathrm{KD}$ was established and the patient received IVIG and aspirin. He became afebrile, 24 hours after IVIG infusion.

\section{CASE 3}

A 1-year-old girl had admitted with complaints of fever, vomiting, and rash. She had a history of high grade fever for 5 days and a rash had started 2 days ago. On admission, the body temperature was $38.5^{\circ} \mathrm{C}$, blood pressure was $80 / 50 \mathrm{mmHg}$ and pulse rate was $110 / \mathrm{min}$. She had bilateral nonpurulant bulbar conjunctivitis, a maculopapular rash on lower extremities, dry and cracked red lips with a strawberry tongue. Anterior cervical lymphadenopathy measuring $1 \times 1 \mathrm{~cm}$ was present. Both hands and feet were not swollen and no desquamation was observed. A diagnosis of KD was made on admission and the patient received IVIG and aspirin. She became afebrile, 32 hours after IVIG infusion.

\section{CASE 4}

A 7-month-old girl had presented with 5-day history of fever, diarrhea and vomiting. 2 days ago cefixime was given with a diagnosis of suspected urinary tract infection with a positive dipstick of leucocytes on urinalysis. The patient's body temperature was $39.0^{\circ} \mathrm{C}$, blood pressure was $70 / 40 \mathrm{mmHg}$ and pulse rate was $132 / \mathrm{min}$. She had bilateral nonpurulent bulbar conjunctivitis, dry and cracked red lips, a strawberry tongue with hypertrophic papillae. Erythema at the site of BCG inoculation was noticed. She didn't have any rash. Extremity examination was normal. She had high erythrocyte sedimentation rate (ESR) and C-reactive protein (CRP), thrombocytosis and leukocytosis on laboratory examination. A diagnosis of incomplete KD was established on 
admission and the patient received IVIG and aspirin. He became afebrile just after IVIG infusion.

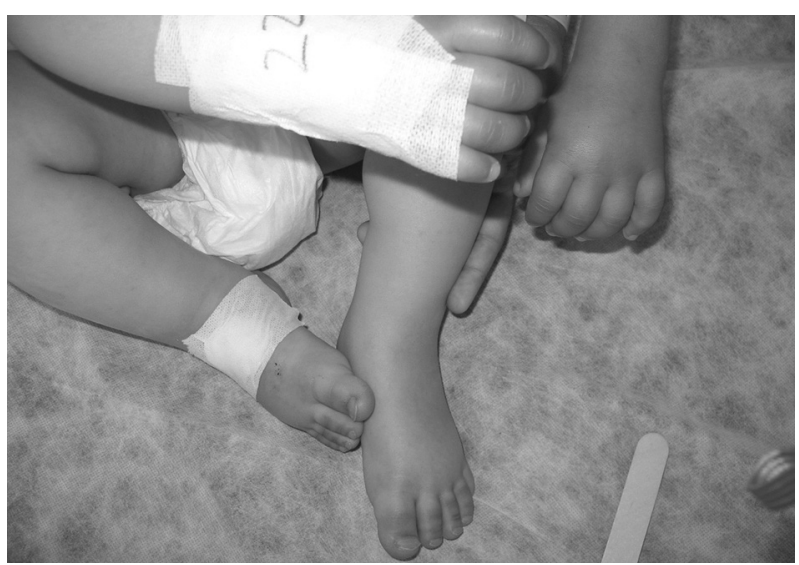

Picture 1. Swelling of the hands and feet of case 1

\section{CASE 5}

An 8-month-old boy had admitted with complaints of fever and rash. He had a history of high grade fever starting 2 days ago and a diffuse rash had started 1 day ago. Physical examination on admission revealed that, the temperature was $38.5^{\circ} \mathrm{C}$, blood pressure was $80 / 60 \mathrm{mmHg}$ and pulse rate was $129 / \mathrm{min}$. He had bilateral nonpurulent bulbar conjunctivitis, dry and cracked red lips, a strawberry tongue, a diffuse maculopapular rash and an anterior cervical lymphadenopathy of $1 \times 1.5 \mathrm{~cm}$ in size. Erythema at the site of BCG inoculation was remarkable (Picture 2). Both hands and feet were swollen but no desquamation was present. A diagnosis of KD was made on admission and the patient received IVIG and aspirin. Because rash and fever had persisted after 72 hours of IVIG treatment, a second dose IVIG of was repeated. He became afebrile, induration of BCG site had disappeared and rash was decreased 12 hours after second IVIG infusion but a desquamation of skin had started on the right hands fingers which was prominent on the thumb. Desquamation did not progress and disappeared after 7 days.

\section{CASE 6}

A 22-month-old girl had admitted with complaints of fever, swelling on neck, cracked lips, arthralgia, swelling of feet and red eyes. She had a 5 days history of high-grade fever reaching up to $40.0^{\circ} \mathrm{C}$ and a diffuse rash which had started 1 day ago. On physical examination, the body temperature was $38.0^{\circ} \mathrm{C}$, blood pressure was $90 / 50 \mathrm{mmHg}$ and pulse rate was
144 /min. She had bilateral nonpurulent bulbar conjunctivitis, dry and cracked red lips, a strawberry tongue, a diffuse maculopapular rash and an anterior cervical lymphadenopathy of $1 \mathrm{x} 1.5 \mathrm{~cm}$ in size. Both feet had been swollen but no desquamation was observed. A diagnosis of KD had been obtained on admission and the patient received IVIG and aspirin. She became afebrile just after IVIG infusion.

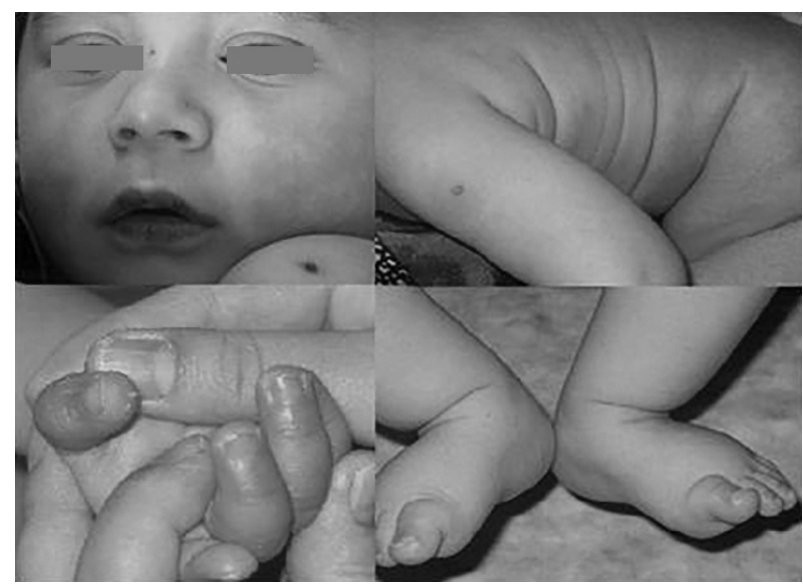

Picture 2. Bilateral nonpurulant bulbar conjunctivitis, dry and cracked red lips, diffuse maculopapular rash, desquamation of fingers and erythema at the site of BCG inoculation of case 5

\section{CASE 7}

An 11-month-old boy had presented with complaints of 7-day history of fever and hyperemia on left shoulder. Hyperemia on shoulder had occurred 2 days ago. Physical examination on admission revealed a temperature of $38.8^{\circ} \mathrm{C}$, a blood pressure of $80 / 50 \mathrm{mmHg}$ and a pulse rate of $138 / \mathrm{min}$. There had been erythema at the site of BCG inoculation and other physical examination findings were normal (Picture 3). On the second day of admission a diffuse maculopapular rash had occurred. He had high ESR, thrombocytosis, hypertransaminasemia and hypertriglyceridemia on laboratory examination. The patient was diagnosed as incomplete KD. He received IVIG and aspirin. He became afebrile just after IVIG infusion. Cracked red lips had been noticed 1 day after IVIG transfusion.

\section{RESULTS}

The clinical and laboratory characteristics are given in Table 1. While 5 cases fulfilled the definition of classical KD, 2 of them were incomplete KD. Ab- 
dominal USG, blood and throat cultures, antibodies against viral pathogens including Ebstein-Barr virus, cytomegalovirus, herpes simplex virus, rubella, toxoplasma, parvovirus B19 and hepatitis A, B, C viruses were negative in all patients. All the patients had received IVIG $2 \mathrm{gr} / \mathrm{kg}$ (total dose) with an infusion of 12 hours. IVIG had been given in the first ten days of the fever to all patients. Also, high dose aspirin $80-100 \mathrm{mg} / \mathrm{kg}$ was started initially till they became afebrile, subsequently they had received $5 \mathrm{mg} / \mathrm{kg} /$ day of aspirin for 6 weeks. Echocardiographic findings and sedimentation rate at the sixth week had been normal in all patients. Only case 5 had been needed a second dose of IVIG because of the persistence of fever despite the first dose IVIG infusion. Repeated echocardiographic examinations had revealed normal findings in all patients. No re- currences had been observed during the follow-up period.

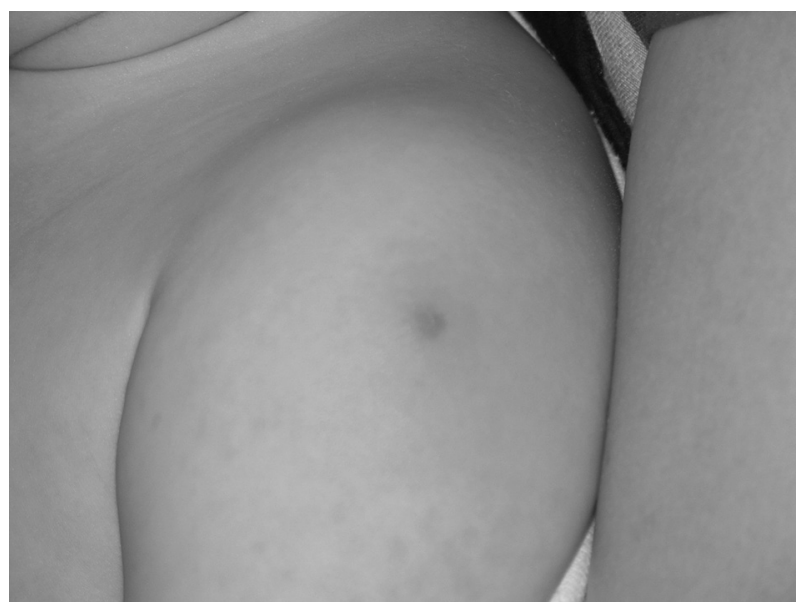

Picture 3. Erythema at the site of BCG inoculation of case 7

Table 1. Clinical and laboratory characteristics of the patients

\begin{tabular}{|c|c|c|c|c|c|c|c|}
\hline Clinical Characteristics & Case 1 & Case 2 & Case 3 & Case 4 & Case 5 & Case 6 & Case 7 \\
\hline Age (month) & 12 & 48 & 12 & 7 & 8 & 22 & 11 \\
\hline Sex & $\mathrm{F}$ & M & $\mathrm{F}$ & $\mathrm{F}$ & M & $\mathrm{F}$ & M \\
\hline Type of KD & Classical & Classical & Classical & Incomplete & Classical & Classical & Incomplete \\
\hline a Duration of Fever (Day) & 9 & 6 & 6 & 5 & 6 & 5 & 9 \\
\hline Rash & + & + & + & - & + & + & + \\
\hline Conjunctivitis & - & + & + & + & + & + & - \\
\hline Oropharynx Changes & + & + & + & + & + & + & - \\
\hline Extremity Changes & + & - & - & - & + & + & - \\
\hline Adenopathy & + & + & + & - & + & + & - \\
\hline Desquamation & - & - & - & - & + & - & - \\
\hline Cardiac Findings & $\mathrm{N}$ & $\mathrm{N}$ & $\mathrm{N}$ & $\mathrm{N}$ & $\mathrm{N}$ & $\mathrm{N}$ & $\mathrm{N}$ \\
\hline BCG Site Induration & - & - & - & + & + & - & + \\
\hline \multicolumn{8}{|l|}{ Laboratory Characteristics } \\
\hline $\mathrm{Hb}(\mathrm{g} / \mathrm{dl})$ & 8.5 & 11.3 & 11.2 & 10.1 & 10.3 & 9.8 & 8.9 \\
\hline WBC $\left(/ \mathrm{mm}^{3}\right)$ & 32900 & 10200 & 10700 & 20000 & 7850 & 14470 & 10500 \\
\hline PIt $\left(x 10^{3} / \mathrm{mm}^{3}\right)$ & 1140 & 486 & 850 & 772 & 737 & 626 & 653 \\
\hline $\mathrm{ESR}(\mathrm{mm} / \mathrm{h})$ & 120 & 45 & 88 & 84 & 36 & 86 & 76 \\
\hline CRP (mg/L) & 215 & 3.3 & 3.4 & 143 & 74.8 & 70.7 & 43.2 \\
\hline AST (IU/L) & 54 & 57 & 30 & 35 & 32 & 23 & 175 \\
\hline ALT (IU/L) & 62 & 31 & 33 & 19 & 133 & 5 & 159 \\
\hline GGT (IU/L) & NM & NM & 244 & 23 & 77 & 7 & 197 \\
\hline $\mathrm{Na}(\mathrm{mEq} / \mathrm{L})$ & 138 & 134 & 140 & 134 & 137 & 138 & 136 \\
\hline Triglyceride (mg/dl) & 382 & NM & NM & 109 & 217 & NM & 207 \\
\hline Albumin (g/dl) & 2.4 & 4.0 & 3.3 & 3.0 & 3.2 & 3.5 & 3.1 \\
\hline Leukocyturia & - & - & - & + & + & - & + \\
\hline
\end{tabular}

a From beginning to end of fever; Hb, hemoglobin; WBC, White Blood Cell Count; PIt, Platelet Count; NM, Not measured; AST, Aspartate Aminotransferase; ALT, Alanine Aminotransferase; GGT, Gammaglutamyl transpeptidase 


\section{DISCUSSION}

The diagnosis of KD is made by persistence of fever for at least 5 days along with 4 of the following signs: polymorphous rash; bilateral conjunctival injection; changes in the peripheral extremities (erythema and/or swelling of the palms and soles; periungual desquamation); changes of the oropharynx (strawberry tongue; injected and/or fissured lips; injected pharynx); cervical lymphadenopathy $(>1.5 \mathrm{~cm}$ diameter) [1]. The term incomplete KD describes the conditions who fail to meet the criteria described above ( $<4$ and $\geq 2$ criteria) and there is no other explanation for the illness. Fukushige et al. reported that $10 \%$ of 242 patients of KD had demonstrated incomplete KD [7]. A particularly high level of suspicion is needed in infants younger than 1 year old, because in a retrospective study consisting of 44 cases, incomplete disease was higher in infants compared to the older children ( $45 \%$ versus $12 \%$ ) [8]. While 5 of the presented patients were in the classical KD, two of them were in the incomplete form and both were under 1-year-old.

Bilateral, nonexudative bulbar conjunctivitis occurs in more than $85 \%$ of patients with KD. Conjunctival injection typically spares the limbus. Inflammation of the palpebral conjunctiva is not prominent [1]. Five (71\%) of our patients had bulbar conjunctivitis.

Cutaneous manifestation of $\mathrm{KD}$ is variable. It usually begins from trunk. While macular, morbiliform or targetoid lesions of trunk and extremities are most characteristic, vesicular and bullous lesions are unusual [1]. It has been reported that rash is absent in $7-10 \%$ of the classical disease, while this rate was $50 \%$ in the incomplete form [7]. Rash was present in 5 cases of our patients. One of the cases $(50 \%)$ with incomplete KD had rash, consistent with the literature.

Anterior cervical lymphadenopathy $(>1.5 \mathrm{~cm}$ diameter) occurring during the acute phase of the disease is usually unilateral. It is the most common absent feature in both classical and incomplete forms [7]. Among the $35 \mathrm{KD}$ patients reported by Kayiran et al. [9], cervical lymphadenopathy was the least common of the principal clinical features. Adenopathy was present in all our patients with the classical form while it wasn't detected in both cases of incomplete form.

Erythema at the site of BCG inoculation is rare, but a specific sign of Kawasaki disease [6]. It is quite often seen in patients with KD at the countries which BCG vaccination is applied. One dose of BCG vaccine by intradermal method to deltoid region of arm is performed to all children aged 2 months in our country. According to the data of Turkish Ministry of Health, $95 \%$ of children born in 2011 have been vaccinated with BCG [10]. BCG reaction has been hypothetically described as a crossreactivity between mycobacterial heat shock protein (HSP) 65 and human homologue HSP 63 [11]. Although $\mathrm{BCG}$ reaction suggests $\mathrm{KD}$ in a patient with fever in the absence of immunodeficiency, BCG reaction and desquamation of extremities has also been reported in the course of HHV 6 infection due to T-cell system activation [12].

Erythema at the site of BCG inoculation is a common finding of KD in Japan. While Hsu et al. [13] reported a $43 \%$ positivity rate of erythema at the site of BCG inoculation, in another study conducted in Japan $49.9 \%$ of the 15524 patients with complete KD had redness or crust formation at the BCG inoculation site. This rate was increased up to $70 \%$ in children aged between 3 to 20 months [14]. Contrary to these reports, this finding is reported to be rare in Turkey $[9,15]$. In the study of Lai et al. [16] conducted in Chorea it was reported that 46 (31.7\%) of 145 patients with KD had a reaction at the site of BCG inoculation. All of these 46 patients were under 20-months-old with the highest rates in patients under 6-months-old. No significant difference was found between complete and incomplete cases. Although laboratory results showed higher white blood cell and platelet counts in patients with BCG site reaction, suggesting an intense inflammation status, no significant difference was seen among coronary artery involvement and response to IVIG treatment [16]. The differences of the age ranges may reflect the different vaccination schedules in different countries, because the development of $\mathrm{BCG}$ reaction reduces 12 months after vaccination $[13,14]$. Three patients had BCG reaction in our study group. All of them were under 12-months-old and vaccinated when they were 2-months old. 
Erythema at the site of BCG inoculation occurs at the 24-48th hours of the fever and regresses with crust formation shortly after fever resolves [17]. In the study of Uehara et al [14], BCG reaction was found to be seen more often in patients admitting on the first 4 days of fever. Fever duration on admission was also found to be shorter in the study of Lai et al [16]. In our study, case 5 who admitted on the second day of fever was rapidly diagnosed as $\mathrm{KD}$ by the presence of BCG reaction.

It has been reported that infants had a higher incidence of incomplete KD and of coronary artery complications [8]. This is also the age group where $\mathrm{BCG}$ reaction is seen more frequently. Seo JH et al. [18] compared 54 complete and 29 incomplete KD patients with BCG reaction and no significant difference was found among clinical, laboratory and echocardiographic findings. No information about the diagnosis and occurrence time of BCG reaction was given in that study. In the study which Lai et al. [16], it was reported that fever duration on admission was found to be shorter in cases with BCG reaction, it was not informed whether the cases were incomplete KD or not.

If early onset of BCG reaction is taken into account, it can be used as a criterion for an early diagnosis especially in patients with incomplete KD [6]. The diagnosis of incomplete KD was confirmed with the finding of BCG reaction in 2 cases (case 4 and 7) in this study. We think that BCG reaction can be a helpful criterion especially in infants with incomplete $\mathrm{KD}$ in Turkey, where BCG vaccination is applied at the age of 2-months with high rates.

Extremity changes of KD include swelling of the dorsum of the hands and feet, a diffuse redpurple erythema of the palms and soles and desquamation. 3 of our patients with classical disease had swelling on hands and feet. Desquamation is reported to occur $68-98 \%$ of the cases usually after the tenth day of the fever [19]. In our study a desquamation of right hand's fingers which was prominent on the thumb was observed only in case 5 at the seventh day of fever.

Swollen cracked red lips, strawberry tongue with hypertrophied papillae are the characteristics of the oropharynx changes. Oropharynx changes were the most common (100\%) feature of KD after fever in our patients. Six of the cases had oropharynx changes on admission. Case 7 with incomplete disease developed cracked red lips after IVIG infusion. Similar to our results, oropharynx changes were reported to be the most common findings in the studies from Turkey $[9,15,20]$.

Tachycardia, myocarditis, pericarditis, gallop rhythm are common cardiac manifestations of the disease. The most significant and characteristic complication of $\mathrm{KD}$ is the development of coronary artery abnormalities (CAA) in up to $25 \%$ of untreated patients. This makes KD the leading cause of acquired heart disease among children in the developed world. Because children with incomplete $\mathrm{KD}$ are also at risk for cardiovascular complications a high level of suspicion is important $[1,21,22]$. Different rates of cardiac involvement were reported from Turkey. While data of Kayiran et al. [9] and Binnetoğlu et al. [15] were consistent with the literature, Gülhan et al. [20] reported a very high rate of CAA which was $42.4 \%$ from 33 patients. Half of these patients (7/14) had developed CAA within eight days after the first fever peak, pointing to the importance of early diagnosis. In our work, all of the cases were diagnosed within the eight days of fever peak and no cardiac manifestation was seen except mild tachycardia.

It is known that there is no specific diagnostic laboratory test for KD. Most of the patients show normochromic normocytic anemia, leukocytosis, elevation of ESR and CRP, hypertransaminasemia, thrombocytosis, hypoalbuminemia, hypertriglyceridemia on laboratory examination [1]. Elevated ESR and thrombocytosis were present in all our patients.

While Burns et al. reported that serum transaminases elevate in $\leq 40 \%$ of patients, Ting et al. reported the elevation rate of gammaglutamyl transpeptidase (GGT) as $\sim 67 \%$. Four $(57 \%)$ and 3 $(42.8 \%)$ of our patients had mild to moderate elevations of serum transaminases and GGT, respectively $[23,24]$.

Supplemental laboratory criteria in the evaluation of suspected incomplete KD include serum albumin $\leq 3.0 \mathrm{~g} / \mathrm{dL}$, anemia for age, elevation of alanine aminotransferase (ALT), platelet count after 7 days $\geq 450,000 / \mathrm{mm}^{3}$, white blood cell (WBC) count $\geq 15,000 / \mathrm{mm}^{3}$ and urine $\mathrm{WBC} \geq 10 /$ high-power field 
[19]. Both of our cases with incomplete disease had anemia, high platelet levels, hypoalbuminemia and leucocyturia. When these two cases were compared, while case 4 had high WBC count $\left(20000 / \mathrm{mm}^{3}\right)$, case 7 had high ALT level (159 IU/L).

If the diagnosis of $\mathrm{KD}$ is relatively certain (even if diagnostic criteria are not met), and other diagnoses have been excluded, treatment should be initiated with aspirin and IVIG without further delay. The American Academy of Pediatrics and the American Heart Association recommend that children with KD should be treated with aspirin and IVIG during the first 10 days of the illness [25,26]. Gulhan et al. [20] recommend this time period to be shortened for Turkish patients because they develop cardiac complications much earlier. Newburger et al. [27] reported that IVIG, and aspirin reduced the risk of coronary artery abnormalities by $78 \%$ compared with those treated with only aspirin. More than $50 \%$ of infants with KD present in the incomplete form, and they have a very high incidence of aneurysms. Thus, empiric treatment in very young children is worthy of consideration. All of our cases were treated with IVIG and aspirin which were given within the first ten days of fever. None of them showed coronary artery abnormalities during the course of the disease and the follow-up period.

In conclusion, KD should be considered as a possible diagnosis in any child presenting with prolonged fever. BCG reaction occurring in the first days of fever can be a useful finding for earlier diagnosis and may be attributed as a diagnostic criterion for incomplete form of the disease especially in countries where BCG vaccination is routinely performed. To prevent long term cardiac morbidity of the disease, early diagnosis and treatment with IVIG and aspirin starting within the first 10 days of fever is crucial.

\section{REFERENCES}

1. Sundel RP, Petty RE. Kawasaki Disease. In: Cassidy JT, Petty RE, eds. Textbook of Pediatric Rheumatology, 6th edn. Philadelphia: Elsevier Saunders, 2011:505-520.

2. Kawasaki T. Acute febrile mucocutaneous syndrome with lymphoid involvement with specific desquamation of the fingers and toes in children. Arerugi 1967;16:178-222.

3. Ozen S, Bakkaloglu A, Dusunsel R, et al. Turkish Pediatric Vasculitis Study Group. Childhood vasculitides in Turkey: a nationwide survey. Clin Rheumatol 2007;26:196-200.
4. Burns JC. Kawasaki disease. Adv Pediatr 2001; 48:157-177.

5. Burgner D, Harnden A. Kawasaki disease: what is the epidemiology telling us about the etiology? Int J Infect Dis 2005; 9:185-194.

6. Plantin P, Blayo M, Dupré D, Schoenlaub P. BCG reactivation: a rare but specific sign of Kawasaki disease. Presse Med 1998; 27:716.

7. Fukushige J, Takahashi N, Ueda Y, Ueda K. Incidence and clinical features of incomplete Kawasaki disease. Acta Paediatr 1994;83:1057-1060.

8. Joffe A, Kabani A, Jadavji T. Atypical and complicated Kawasaki disease in infants. Do we need criteria? West J Med 1995; 162:322-327.

9. Kayiran SM, Dindar A, Gurakan B. An evaluation of children with Kawasaki disease in Istanbul: a retrospective followup study. Clinics 2010;65:1261-1265.

10. Başara BB, Güler C, Eryılmaz Z, ve ark. T.C. Sağlık Bakanlığ1 Sağlık İstatistikleri Y1llı̆̆ 2011, Bölüm:5 Sayfa:49, Ankara, Türkiye, 2012.

11. Sireci G, Dieli F, Salerno A. T cells recognize an immunodominant epitope of heat shock protein 65 in Kawasaki disease. Mol Med 2000;6:581-590.

12. Kakisaka Y, Ohara T, Katayama S, et al. Human herpes virus type 6 can cause skin lesions at the BCG inoculation site similar to Kawasaki Disease. Tohoku J Exp Med 2012;228:351-353.

13. Hsu YH, Wang YH, Hsu WY, Lee YP. Kawasaki disease characterized by erythema and induration at the Bacillus Calmette-Guérin and purified protein derivative inoculation sites. Pediatr Infect Dis J 1987;6:576-578.

14. Uehara R, Igarashi H, Yashiro M, et al. Kawasaki disease patients with redness or crust formation at the Bacille Calmette-Guérin inoculation site. Pediatr Infect Dis J 2010;29:430-433.

15. Binnetoğlu K, Kuşdal Y, Altun G, Babaoğlu K. Kocaeli Bölgesinde Kawasaki Hastalığı Tanısı Alan 24 Hastanın Klinik ve Epidemiyolojik Özellikleri. Çocuk Enf Derg 2010; 4:71-75.

16. Lai CC, Lee PC, Wang CC, et al. Reaction at the bacillus Calmette-Guérin inoculation site in patients with Kawasaki disease. Pediatr Neonatol 2013;54:43-48.

17. Takayama J, Yanase Y, Kawasaki T. A study on erythematous change at the site of the BCG inoculation. Acta Pediatr Jpn 1982;86:567-572.

18. Seo JH, Yu JJ, Ko HK, et al. Diagnosis of incomplete Kawasaki disease in infants based on an inflammation at the Bacille Calmette-Guérin inoculation site. Korean Circ J 2012;42:823-829.

19. Wang S, Best BM, Burns JC. Periungual desquamation in patients with Kawasaki disease. Pediatr Infect Dis J 2009;28:538-539.

20. Gülhan B, Kesici S, Beken S, et al. Varying clinical features of Turkish Kawasaki disease patients. Turk J Pediatr 2012;54:1-6.

21. Ozdemir H, Ciftçi A, Karbuz A, et al. Incomplete Kawasaki disease in an infant presenting with only prolonged fever Turk J Pediatr 2013; 55:529-532. 
22. Ozdemir H, Ciftçi E, Tapisiz A, et al. Clinical and epidemiological characteristics of children with Kawasaki disease in Turkey. J Trop Pediatr 2010;56:260-262.

23. Burns JC, Mason WH, Glode MP, et al. Clinical and epidemiologic characteristics of patients referred for evaluation of possible Kawasaki disease. United States Multicenter Kawasaki Disease Study Group. J Pediatr 1991;118:680686.

24. Ting EC, Capparelli EV, Billman GF, et al. Elevated gamma-glutamy 1 transferase concentrations in patients with acute Kawasaki disease. Pediatr Infect Dis J 1998;17:431432.

25. Newburger JW, Takahashi M, Gerber MA, et al; Committee on Rheumatic Fever, Endocarditis, and Kawasaki Disease, Council on Cardiovascular Disease in the Young, Ameri- can Heart Association. Diagnosis, treatment, and long-term management of Kawasaki disease: a statement for health professionals from the Committee on Rheumatic Fever, Endocarditis, and Kawasaki Disease, Council on Cardiovascular Disease in the Young, American Heart Association. Pediatrics 2004;114:1708-1733.

26. American Academy of Pediatrics. Kawasaki disease. In: Pickering LK, Baker CJ, Long SS, McMillan JA, eds. Red Book: 2006 Report of the Committee on Infectious Diseases, $27^{\text {th }}$ edn. Elk Grove, Village, IL: American Academy of Pediatrics; 2006: 414.

27. Newburger JW, Takahashi M, Burns JC, et al. The treatment of Kawasaki syndrome with intravenous gamma globulin. N Engl J Med 1986;315:341-347. 